\title{
Simone de Beauvoir i brev och dagbok
}

\section{Av Christina Angelfors, universitetslektor i franska}

\author{
Länk till presentation av Christina Angelfors
}

Platsen är Paris i april 1980. Jag befinner mig tillsammans med mina vänner i ett oändligt hav av människor som sakta, sakta rör sig framåt. Vi är på väg mot Montparnassekyrkogården. Alla är vi medvetna om att det vi nu upplever är ett historiskt ögonblick. Personen för vars skull vi samlats är Jean-Paul Sartre. Den som eventuellt inte tidigare förstått vilken central plats Sartre alltid haft i franskt intellektuellt och politiskt liv får nu upp ögonen. I begravningståget går mestadels unga människor i tjugofem- till trettioårsåldern, människor som alltså känner att Sartre och det han stått för fortfarande angår dem. Stämningen är högtidlig. Det verkar som om alla känner att här finns ett arv att bära vidare.

Nästa scen utspelar sig sex år senare, fortfarande i april månad. Folkmassan är denna gång inte riktigt lika överväldigande. Större delen består av kvinnor. Även nu är vårt mål Montparnasse och kyrkogården där.Ansiktena runt omkring mig präglas av uppriktig sorg och saknad. Med Simone de Beauvoirs bortgång har en förebild för många kvinnor gått ur tiden, en modell för hur man som kvinna kan lyckas med sitt liv.

Ja, så kände jag och många med mig vid den här tiden. Visserligen hade bilden av paret Beauvoir-Sartre fått sig en törn i och med publiceringen, 1983, av Sartres brev till Beauvoir, Lettres au Castor et à quelques autres. Breven bekräftar egentligen endast vad Beauvoir själv sagt i sina memoarer. Både i Mémoires d'une jeune fille rangée (1958) och i La Force de l'âge (1960) beskriver Beauvoir deras förhållande som klart "ojämlikt": "un mariage morganatique" (1960, I, 25). Med andra ord ett äktenskap mellan en furstlig man och en icke jämbördig kvinna. Beauvoir intar självmant positionen som "den andra" i detta förhållande. Hon beundrar och ser upp till Sartre, vars intelligens hon anser överlägsen hennes egen.

Så länge man som läsare endast hade Beauvoirs egen bild av Sartre att gå efter var man givetvis benägen att dela hennes beundran för denne till synes fantastiske man. Men vad Sartres brev avslöjar är alltså att han i långa stycken, särskilt på det känslomässiga planet, tycks ha varit en ganska vidrig människa, som handskades helt egoistiskt och hänsynslöst med de kvinnor som kom i hans väg. Simone de Beauvoir, som själv svarat för utgivningen av dessa brev, anger i förordet att hon gjort vissa strykningar med hänsyn till tredje person. Den fullständiga brevsamlingen finns deponerad på Bibliothèque Nationale i Paris och är nu tillgänglig för forskare. Av en amerikansk kollega, som gått igenom materialet, har jag fått veta att de strykningar som gjorts alla har till syfte att dämpa den negativa bild av Sartre som avtecknar sig i breven. Ännu har vi alltså inte alla pusselbitar i vår hand. Men jag är ganska övertygad om att vad som än yppar sig kommer förtroendet för Sartre som människa och intellektuell inte heller nu att rubbas. På den punkten kan man konstatera en avgörande skillnad mellan mottagandet av Sartres brev och de mycket negativa reaktioner som publiceringen av Beauvoirs del av brevväxlingen har framkallat.

När Beauvoir gav ut Sartres brev uppfyllde hon på sätt och vis hans egen önskan. I ett samtal de haft några år innan hans bortgång hade Sartre låtit förstå att han såg sina brev som ett levande och direkt vittnesbörd om hans liv och att han alltid skrivit med den baktanken att breven skulle ges ut efter hans död. I förordet till Beauvoirs Lettres à Sartre (1990) anger Sylvie Le Bon, Beauvoirs adoptivdotter, liknande skäl till varför hon bestämt sig för att offentliggöra Beauvoirs brev. Simone de Beauvoir påstod alltid själv att hennes 
brev kommit bort men medgav att om de händelsevis skulle komma tillrätta fick de ges ut efter hennes död. Inga eller mycket få strykningar har gjorts, enligt Le Bon, som menar att det nu är dags att låta människan Simone de Beauvoir träda fram utan mask. Sanningen kräver att allt sägs. För att bilden ska bli fullständig publicerar Le Bon samma år Beauvoirs dagbok från krigsåren 1939-41. De utgör ett komplement till korrespondensen eftersom mer än hälften av breven är skrivna under den här perioden.

Om vi får tro Sylvie Le Bon är det alltså den "sanna", den "verkliga" Simone de Beauvoir som vi får möta i detta självbiografiska material. Men som alla som skolats i "misstankens" hermeneutik vet är den litterära texten ett märkligt fenomen, som tenderar att leva sitt eget liv, att följa sina egna lagar. Särskilt misstänksam bör man nog vara mot texter skrivna i jag-form, som t ex dagböcker. Det vanligaste syftet med att föra dagbok är väl att man vill nå en djupare förståelse av sig själv och sin omvärld genom att dag för dag notera vad som händer en. Detta är också fallet med Simone de Beauvoir. Hon börjar sina anteckningar i september 39, i och med krigsutbrottet, därför att hon är nyfiken på sina egna reaktioner inför den omvälvning som stundar (Journal, 77). Normalt sett är en dagbok inte avsedd för någon publik, vilket förmodas prägla uttryck och innehåll. Beauvoirs fall är dock speciellt. För det första tjänar dagboken som underlag för breven till Sartre, som vid denna tid ligger inkallad. För det andra låter hon Sartre direkt ta del av sina anteckningar antingen genom att skicka utdrag eller visa honom dagboken de gånger han har permission. Såväl dagbok som brev har alltså en uttrycklig adressat. Detta menar jag är en viktig faktor att ta hänsyn till om man, som jag, vill försöka analysera fram en bild av Simone de Beauvoir ur detta material. Rousseau, i arbetet med sina Confessions, formulerade problemet med självbiografier på följande sätt:

Nul ne peut écrire la vie d'un homme que lui-même. Sa manière d'être intérieure, sa véritable vie n'est connue que de lui; mais en l'écrivant il la déguise; /.../ il se montre comme il veut être vu, mais point du tout comme il est. (min kursivering)

En annan aspekt av den här frågan är givetvis om det överhuvudtaget är möjligt för oss att känna oss själva och om vi i så fall kan förmedla denna kunskap till vår omgivning. Vi vet att Sartre senare kommer att formulera en teori om att självkännedom endast är möjlig genom förmedling av den andre, av den andres blick på mig som gör att jag kan se mig själv som ett objekt (L'Etre et le néant, 1943).

När man sysslar med självbiografiskt material måste man också rent berättartekniskt ta hänsyn till att det berättande "jaget" inte är exakt detsamma som det "jag" som det berättas om. I memoarer kan avståndet mellan dessa båda "jag" vara avsevärt, beroende på personlig utveckling och på hur lång tid som skiljer mellan nu och då. I brev och dagbok är avståndet i princip minimalt men bör inte negligeras.

Korrespondensen mellan Beauvoir och Sartre, Beauvoirs dagbok och Sartres Carnets de la drôle de guerre, dvs. hans dagboksanteckningar från perioden september 39 till juni 1940, varav fem publicerades 1983 och en 1995, har gett forskningen mycket nytt och rikt stoff att arbeta med. Vad Simone de Beauvoir beträffar, som ju redan hade en omfattande memoarserie bakom sig, innebär det nya materialet att vi får inblick i hittills helt okända delar av hennes liv, alltså en indirekt bekräftelse på hur otillförlitliga en författares memoarer kan vara. Den del som jag hittills ägnat mig åt är just tiden mellan 39 och 40, under vilken dagboksanteckningar och brev sammanfaller. De händelser som det berättas om under den här perioden kan enligt min mening ge oss en fördjupad kunskap om hur Beauvoir upplever sin egen identitet som kvinna och i förlängningen av detta förhoppningsvis en större insikt i frågan om sexuell identitet och identifikation i allmän bemärkelse

Som bakgrund bör vi veta att Beauvoir och Sartre på ett tidigt stadium i sitt förhållande slutit ett antal "avtal": aldrig ljuga för varandra, aldrig dölja något för varandra. Dessutom hade Sartre förklarat att han ingalunda tänkte avstå från andra kvinnor bara för Beauvoirs 
skull: "Entre nous, m'expliquait-il en utilisant un vocabulaire qui lui était cher, il s'agit d'un amour nécessaire : il convient que nous connaissions aussi des amours contingentes" (min kurs.) (LFA,I. 28). Detta är utgångspunkten för de synnerligen komplicerade relationer som så småningom kommer att prägla den krets av män och kvinnor som Beauvoir och Sartre omger sig med. Vid den tidpunkt som intresserar oss här finns i Beauvoirs liv förutom Sartre en ung man som tidigare varit Sartres elev, samt två unga kvinnor som är före detta elever till henne själv.

Brevväxlingens främsta syfte är givetvis att upprätthålla kontakten under den tid Sartre är inkallad. Det är en livsnödvändighet för båda att inte avbryta den ständiga dialog som hela deras relation tycks vila på. Genom breven känner de att de fortfarande är förenade "unis". Detta att vara förenad, att utgöra ett - "on ne fait qu'un"- är något som de båda ständigt återkommer till. Det finns alltså ett starkt drag av identifikation mellan Beauvoir och Sartre. De gör samma saker: båda för dagbok, främst för att kunna visa den andre; båda skriver på en roman, Beauvoir på L'Invitée och Sartre på L'Age de la raison. Intrig och idéinnehåll jämförs och diskuteras. Beauvoir uttrycker en önskan om att hennes brev ska få Sartre att känna att hans liv fortsätter genom henne; det främsta syftet med allt hon upplever är att kunna berätta det för honom och på så sätt berika hans liv (Lettres, I, 124, 144). Sartre instämmer i detta synsätt: "vous vivez pour moi ma vie" (Lettres, I, 333). Längre i identifikation med den andre kan man knappast komma.

Ett uttryck som Sartre ofta använder är: "vous êtes moi", som om han såg Beauvoir som en spegelbild av sig själv. Beauvoir använder uttrycket en gång, men då inom citationstecken (Lettres, I, 272), dvs. som om hon citerade Sartre. Man har en känsla av att uttrycket inte har samma självspeglande innebörd för henne som för honom. Jag har redan nämnt att Beauvoir alltid betraktade Sartre som intellektuellt överlägsen henne själv. Jag tror att det är den känslan som gör att identifikationsprocessen sedd ur hennes synvinkel ter sig något annorlunda. När hon berättar om den här tiden i sina memoarer betecknar hon visserligen Sartre som "son double", "son égal", men det hindrar inte att känslan av underlägsenhet finns där parallellt. Möjligen skulle man kunna tillskriva dessa termer det berättande "jaget", med andra ord att hon med åren kommit att känna sig mer jämbördig. Men detta återstår att bevisa.

Sartre är alltså hon själv men samtidigt något mer än hon själv. I brevväxlingen avspeglas detta förhållande i termer som att hon känner sig "amputée" utan honom (I, 136), han är den föda som hon behöver för att leva (I, 128); om han dog skulle hon vissna bort osv (I, 130). Hon framställer t o m hela sitt liv som en produkt av Sartres idéer: "ce n'est pas seulement nos rapports que vous avez réussis, c'est vraiment votre vie, votre morale, et ma vie à moi aussi par contrecoup" (I, 168). En viktig aspekt av hennes identifikation med Sartre tycks alltså vara att hon till viss del känner sig "skapad" av honom. Detta är något helt annat än att se den andre som sin spegelbild.

Trots den starka identifikationen med Sartre, alltså med en manlig modell, uppfattar man ändå Beauvoir som "kvinnlig" i förhållande till honom. Kanske är en av orsakerna till detta just underlägsenhetskänslan, som ju präglar hela hennes beteende. Om man ser på Beauvoirs relationer till andra kvinnor existerar inte den dimensionen, vilket kan vara en möjlig förklaring till varför hennes agerande i dessa fall uppfattas som "manligt", inte bara av läsaren utan också av henne själv. Exemplen på sådant s k "manligt" beteende är otaliga i såväl dagbok som brev.

I november 39 noterar Beauvoir i sin dagbok: "Hier soir je parle longtemps avec Sartre d'un point qui m'intéresse en moi justement, c'est ma "féminité", la manière dont je suis de mon sexe et n'en suis pas" (126). Detta är med andra ord det första fröet till den frågeställning som hela Le Deuxième Sexe kommer att bygga på, dvs. att könsidentiteten är en social konstruktion. Vad är det då i hennes eget liv som får henne att börja fundera i dessa banor? Något explicit svar ges inte, men man får förmoda att den typ av relationer som paret lever i vid denna tid spelar en viss roll. 
Jag nämnde i början att Simone de Beauvoirs gloria hamnat lite på sned efter de "sanningar" som avslöjats i hennes brev och dagbok. Vissa har t o m tappat tron på giltigheten i hela hennes teoretiska arbete på grund av detta. Men liv och teori måste kanske inte nödvändigtvis stämma överens, teorin kan vara giltig ändå. Simone de Beauvoir har visat oss - sin publik - ett mycket stort förtroende genom att låta oss se henne som den hon var. Det är vår uppgift att visa oss värdiga det förtroendet.

\section{(C) Christina Angelfors}

